\title{
Teaching remotely during the COVID-19 pandemic: perceptions from and psychological impact on health science professors in Brazil
}

\author{
Ensino remoto durante a pandemia COVID-19: percepções e impacto psicológico em professores de \\ ciências da saúde no Brasil \\ Enseñar a distancia durante la pandemia COVID-19: percepciones e impacto psicológico en \\ profesores de ciencias de la salud en Brasil
}

Received: 12/07/2021 | Reviewed: 12/12/2021 | Accept: 12/17/2021| Published: 12/22/2021

\author{
Andrezza Lauria \\ ORCID: https://orcid.org/0000-0002-6577-8468 \\ Universidade Federal do Amazonas, Brazil \\ E-mail: andrezzalauria@gmail.com \\ Gabriela Mayrink \\ ORCID: https://orcid.org/0000-0003-2436-8216 \\ FAESA Centro Universitário, Brazil \\ E-mail: gabimayrink@gmail.com \\ Fernanda Mayrink Gonçalves Liberato \\ ORCID: https://orcid.org/0000-0001-5227-2022 \\ Universidade Federal do Espírito Santo, Brazil \\ E-mail: nandamayrink@yahoo.com.br \\ Clarice Maia Soares de Alcântara Pinto \\ ORCID: https://orcid.org/0000-0002-0209-1482 \\ Fametro Centro Universitário, Brazil \\ E-mail: claricemsalcantara@yahoo.com.br \\ Patrick Filgueiras da Silva \\ ORCID: https://orcid.org/0000-0002-3016-1468 \\ Universidade Federal do Amazonas, Brazil \\ E-mail: Patrick_silva@ufam.edu.br \\ Lucas Rodrigues Nascimento \\ ORCID: https://orcid.org/0000-0002-6792-0819 \\ Universidade Federal do Espírito Santo, Brazil \\ E-mail: prof.lucasnascimento@gmail.com
}

\begin{abstract}
With the social distancing required by the coronavirus (COVID-19) pandemic, the creation of a new pedagogical model became a sudden challenge for educational institutions. This study sought to assess health science professors' experiences and perceptions during the COVID-19 pandemic. An epidemiological, descriptive, cross-sectional, observational, and quantitative approach was applied and included the application of a structured and selfadministered virtual questionnaire containing objective and multiple-choice questions on demographic data, online teaching activities, continuing education, learning environments, and difficulties faced. Seven questions from the Generalized Anxiety Disorder Screening Tool (GAD-7) were added to assess anxiety. One hundred and thirty-eight university professors in Brazil completed the questionnaire. Of these, 87 were employed by public institutions and 51 worked at private institutions. Geopolitical region in the country and university funding type were associated with universities' ability or decision to offer courses online. Among the professors, being of female gender and a decrease in household income were the factors most closely associated with increased anxiety. Professors also reported difficulties in interacting with students online, the need to assume more childcare, and difficulty in concentrating at home to be the main barriers to successful online teaching.
\end{abstract}

Keywords: Faculty; COVID-19; Health education; Anxiety; Education, distance.

\section{Resumo}

Com o distanciamento social exigido pela pandemia do coronavírus (COVID-19), a criação de um novo modelo pedagógico tornou-se um repentino desafio para as instituições de ensino. Este estudo buscou avaliar as experiências e percepções dos professores de ciências da saúde durante a pandemia COVID-19. Foi aplicada uma abordagem epidemiológica, descritiva, transversal, observacional e quantitativa, que incluiu a aplicação de um questionário virtual estruturado e autoaplicável contendo questões objetivas e de múltipla escolha sobre dados demográficos, atividades de ensino online, educação continuada, ambientes de aprendizagem, e as dificuldades enfrentadas. Sete 
perguntas da Ferramenta de Triagem de Transtorno de Ansiedade Generalizada (GAD-7) foram adicionadas para avaliar a ansiedade. Cento e trinta e oito professores universitários no Brasil responderam ao questionário. Destes, 87 trabalhavam em instituições públicas e 51 trabalhavam em instituições privadas. A região geopolítica do país e o tipo de financiamento da universidade foram associados à capacidade ou decisão das universidades de oferecer cursos online. Entre os professores, ser do sexo feminino e a diminuição da renda familiar foram os fatores mais associados ao aumento da ansiedade. Os professores também relataram dificuldades em interagir com os alunos online, a necessidade de assumir mais os cuidados com os filhos e a dificuldade de concentração em casa como as principais barreiras para o sucesso do ensino online.

Palavras-chave: Docentes; COVID-19; Educação em saúde; Ansiedade; Ensino à distância.

\section{Resumen}

Con el distanciamiento social que requería la pandemia del coronavirus (COVID-19), la creación de un nuevo modelo pedagógico se convirtió en un desafío repentino para las instituciones educativas. Este estudio buscó evaluar las experiencias y percepciones de los profesores de ciencias de la salud durante la pandemia de COVID-19. Se aplicó un enfoque epidemiológico, descriptivo, transversal, observacional y cuantitativo que incluyó la aplicación de un cuestionario virtual estructurado y autoadministrado que contiene preguntas objetivas y de opción múltiple sobre datos demográficos, actividades de enseñanza en línea, educación continua, entornos de aprendizaje, y dificultades enfrentadas. Se agregaron siete preguntas de la herramienta de detección de trastornos de ansiedad generalizada (GAD-7) para evaluar la ansiedad. Ciento treinta y ocho profesores universitarios de Brasil completaron el cuestionario. De estos, 87 fueron empleados por instituciones públicas y 51 trabajaron en instituciones privadas. La región geopolítica del país y el tipo de financiación universitaria se asociaron con la capacidad o la decisión de las universidades de ofrecer cursos en línea. Entre los profesores, ser de sexo femenino y una disminución de los ingresos familiares fueron los factores más estrechamente asociados con el aumento de la ansiedad. Los profesores también informaron que las dificultades para interactuar con los estudiantes en línea, la necesidad de asumir más cuidados de los niños y la dificultad para concentrarse en casa son las principales barreras para una enseñanza en línea exitosa.

Palabras clave: Docentes; COVID-19; Educación en salud; Ansiedad; Educación a distancia.

\section{Introduction}

In recent decades, many educational institutions worldwide have varied their teaching methods by incorporating new technologies (namely, the internet) and treating students as the protagonists in the classroom; these changes, however, have been slow to take root in most universities in Brazil (Rose, 2020; Kemp \& Grieve, 2014).

Although many universities around the world have adopted more student-centered teaching methods and have incorporated virtual and computer-based activities into their curricula, theoretical classes taught solely online are not the routine of most health-care-related degree programs. Some studies have shown that virtual classes can produce student outcomes that are as good results as face-to-face lessons (Kemp \& Grieve, 2014; Bielschowsky, 2018), but to ensure the effectiveness of online learning, it is necessary that the design principles of digital teaching materials, learning objectives, and student preferences be rigorously assessed (Pei \& Wu, 2019).

With the sudden change in teaching methods required of the coronavirus pandemic, professors and institutions had little time to adapt. Professors faced challenges applying new methods and technologies that they often had not yet mastered, a situation which could generate high levels of stress (Vieira et al., 2021, Bianchi, 2021, Silva et al, 2021, Klapproth et al, 2020; Baker et al, 2020; Li, 2020). The purpose of this study was to describe university health care and health sciences degree program professors' distance learning experiences during the COVID-19 pandemic in Brazil. The specific questions that the study sought to address were:

1. Which factors have been associated with the use of distance learning to educate health science students during the COVID-19 pandemic?

2. Which factors have been associated with anxiety among professors who have been teaching remotely during the COVID-19 pandemic relative to professors who have not been teaching remotely?

3. According to professors, what are the main barriers to distance learning experienced by health science professors? 


\section{Methodology}

\section{Study Design}

A descriptive, cross-sectional, observational, and epidemiological study with a quantitative approach was performed. It relied on an online questionnaire created by the researchers. The survey was sent to university professors from health science degree programs offered across Brazil's different geopolitical regions. The health-care-related degree programs included in this study were dentistry, medicine, physical therapy, nutrition, nursing, biomedicine, speech pathology, physical education, and occupational therapy. Institutions that offer these health science programs were sent a questionnaire to investigate professors' personal experiences and institutional details on distance education and asked to send the questionnaire to eligible professors. The Generalized Anxiety Disorder Screening Tool, or GAD-7 (Spitzer et al, 2006) was also added to the questionnaire. It is composed of seven questions that assess anxiety.

This study was approved by the ethical review board of Federal University of Amazonas in Manaus, Amazonas State, Brazil (CAE Registry No. 33528220.6.0000.5020), and the participants provided written consent prior to data collection.

\section{Participants and Sampling}

Professors were considered eligible for the study if they were currently employed as professors at higher education institutions, taught courses in the health sciences, accessed the questionnaire through the official link, and provided written consent. The questionnaires were sent by each included institution to their professors via email or by the researchers to professors in chat groups on messaging apps. The final sample consisted of professors who answered the questionnaires and reported teaching health science courses.

\section{Program Details and Study Groups}

Professors were put into one of two groups based on the semester in their respective programs in which their students were enrolled. It is important to note that, in most Brazilian universities, all students enrolled in a given undergraduate degree program complete the same courses in the same order. The first group consisted of professors who taught students enrolled in fourth semester courses or below, while the second group consisted of professors who taught upper-division courses to students enrolled in the fifth semester or above. This distinction was made in some of the calculations because the lowerdivision courses in most health science programs are more theoretical in nature, while the upper-division courses tend to be practical and involve clinical or laboratory work. The courses were defined as theoretical, clinical, or laboratory-based. Theoretical courses were those taught only in a classroom or lecture hall before the pandemic, while laboratory-based courses involved practical activities, and clinical courses involved treating patients.

Professors' academic activities were defined as remote teaching or remote activities when the work was completed exclusively online; professors not teaching remotely were defined as those whose teaching work was suspended altogether and who were teaching neither online classes nor face-to-face classes.

\section{The Questionnaire}

The questionnaire was divided into three sections:

The first section was applied to professors of all of the health-care-related degree programs included and was used to obtain information about the participants' personal and demographic data (such as gender, geopolitical region of the country where they taught, age, household income, and internet access at home), as well as professional data (such as the funding type of the institution where they taught, courses taught, and experience with distance learning prior to the pandemic). 
The questions answered in the second section depended on the professors' pandemic experience. The professors received different questions based on whether they had been teaching online or had not been teaching during the pandemic but had participated in other academic activities.

The third and final section was again given to all participating professors and included questions from the previously validated GAD-7.

\section{Outcomes of Interest}

The two outcomes were of interest were professors' experiences with distance learning and professors' anxiety during the COVID-19 pandemic. Distance learning was dichotomized into yes or no based on the following question: "Are you currently teaching remotely during the Covid-19 pandemic?" GAD-7 measurements of anxiety levels were calculated as scores ranging from 0 to 21, where higher scores indicated more symptoms of anxiety (Hinz et al., 2017). The GAD-7 has already been proven to be a reliable instrument for measuring anxiety in the general population and has been translated into Portuguese (Hinz et al, 2017; Bergerot et al., 2014).

Other factors investigated included the professors' familiarity with online education and with internet and related technology in general, information on any remote education training provided by the institution, the option of a home environment appropriate for teaching or participating in administrative activities remotely, and the correlation of all of these factors with anxiety.

\section{Data Analysis}

The data were tested for normality using the Kolmogorov-Smirnov test, and descriptive data were provided. The mean and standard deviation have been reported for continuous data, and frequency and percentages have been reported for categorical data. Chi-square tests or Pearson correlation coefficients were used to identify univariate variables associated with the university's offering of remote education and with anxiety symptoms, depending on whether the variable was continuous or categorical. The significance level was set at $\mathrm{p}<0.05$. Significant variables were included in the linear or logistic regression analyses, which was performed using R Statistical Software, version 3.4.0.

\section{Results}

A total of 138 professors completed the questionnaire. Table 1 lists several variables to describe the participants and presents the results of the study sample as a whole and divided into those who were teaching remotely or not. Of Brazil's five established geopolitical regions, the professors were from only three of them, and 51\% of participants taught in Brazil's most economically developed Southeast region. Of the professors who participated in the study, 112 (82\%) had never taught online classes before the pandemic, 71 (51\%) were teaching remotely during the pandemic, and 69\% worked at private institutions. 
Table 1 - Characteristics of the professors who completed the COVID-19 distance education and anxiety questionnaire provided in this study.

\begin{tabular}{|c|c|c|c|}
\hline Characteristic & $\begin{array}{l}\text { All } \\
(n=138)\end{array}$ & $\begin{array}{l}\text { Teaching Remotely } \\
(n=71)\end{array}$ & $\begin{array}{ll}\text { Not } & \text { Teaching } \\
\text { Remotely } & \\
(\mathrm{n}=67) & \\
\end{array}$ \\
\hline Age, mean (SD) & $43(10)$ & $44(11)$ & $42(8)$ \\
\hline Gender, $n$ male (\%) & $52(38)$ & $33(47)$ & $19(28)$ \\
\hline \multicolumn{4}{|l|}{ Geopolitical region of Brazil, $\mathbf{n}(\%)$} \\
\hline North & $53(38)$ & $24(34)$ & $29(43)$ \\
\hline Northeast & $14(10)$ & $14(20)$ & $0(0)$ \\
\hline Southeast & $71(51)$ & $33(47)$ & $38(57)$ \\
\hline Number of household residents, mean (SD) & $3(1)$ & $3(1)$ & $3(1)$ \\
\hline Household income (US\$), mean (SD) & $3600(1900)$ & $3700(1900)$ & $3400(1900)$ \\
\hline \multicolumn{4}{|l|}{ Level of Courses Taught, $\mathbf{n}(\%)$} \\
\hline Lower division (students' $4^{\text {th }}$ semester or lower) & $13(9)$ & $10(14)$ & $3(4)$ \\
\hline Upper division (students' $5^{\text {th }}$ semester or higher) & $59(43)$ & $29(41)$ & $30(45)$ \\
\hline Both upper- and lower-division courses & $66(48)$ & $32(45)$ & $34(51)$ \\
\hline \multicolumn{4}{|l|}{ Type of Courses Taught, $\mathbf{n}(\%)$} \\
\hline Theoretical & $12(9)$ & $9(13)$ & $3(5)$ \\
\hline Theoretical and clinical & $87(63)$ & $46(65)$ & $41(61)$ \\
\hline Theoretical and laboratory-based & $36(26)$ & $16(23)$ & $20(30)$ \\
\hline Clinical & $2(2)$ & $0(0)$ & $2(3)$ \\
\hline \multicolumn{4}{|l|}{ Institution's Funding Source, $\mathbf{n}(\%)$} \\
\hline Public & $87(63)$ & $22(31)$ & $65(97)$ \\
\hline Private & $51(37)$ & $49(69)$ & $2(3)$ \\
\hline \multicolumn{4}{|l|}{ Remote Teaching Experience before Pandemic, n (\%) } \\
\hline Yes & $26(18)$ & $16(22)$ & $10(14)$ \\
\hline No & $112(82)$ & $55(78)$ & $57(86)$ \\
\hline \multicolumn{4}{|l|}{ Enrolled in courses on distance learning, $\mathrm{n}(\%)$} \\
\hline Yes & $120(87)$ & $64(90)$ & $56(84)$ \\
\hline No & $18(13)$ & $7(10)$ & $11(16)$ \\
\hline
\end{tabular}

Source: Applied questionnaires.

In the assessment of associations between distance education and the other variables (Table 2), gender, geopolitical region, and institution's funding source were found to be significantly correlated with professors' online teaching status; the respective p-values were $0.03,<0.01$, and $<0.01$. The two factors found to be associated with anxiety during the COVID-19 pandemic were gender $\left(\mathrm{x}^{2}=32.20, p=0.04\right)$ and household income $(\mathrm{r}=-0.26 ; p<0.01)$, which, when combined, explained 18\% of the variance associated with anxiety (Nagelkerke R2=0.18). People with lower household incomes presented more anxiety symptoms than those with higher household incomes, and women reported more anxiety symptoms than men (SD: 3.7 points; 95\%CI: 2.1 to 5.3$)$.

Table 2 - Associations between population characteristics and teaching remotely (yes/no) and between population characteristics and GAD-7 scores.

\begin{tabular}{lll}
\hline Characteristic & Teaching Remotely & GAD-7 \\
\hline Age & NA & $\mathrm{r}=-0.20 ; p=0.07$ \\
Gender & NA & $x^{2}=32.20 ; p=0.04^{*}$ \\
Region in Brazil & $x^{2}=14.72 ; p<0.01^{*}$ & $x^{2}=38.52 ; p=0.54$ \\
No. of household residents & NA & $\mathrm{r}=-0.05 ; p=0.59$ \\
Household income & $x^{2}=28.22 ; p=0.40$ & $\mathrm{r}=-0.26 ; p<0.01^{*}$ \\
Level of courses taught & $x^{2}=3.73 ; p=0.15$ & $x^{2}=51.30 ; p=0.11$ \\
Type of courses taught & $x^{2}=6.62 ; p=0.15$ & $x^{2}=56.40 ; p=0.98$ \\
Institution's funding source & $x^{2}=64.50 ; p<0.01^{*}$ & $x^{2}=14.24 ; p=0.82$ \\
Remote teaching experience before the pandemic & $x^{2}=1.81 ; p=0.17$ & $x^{2}=21.66 ; p=0.30$ \\
Enrolled in courses on distance education & $x^{2}=1.30 ; p=0.25$ & $x^{2}=20.42 ; p=0.43$ \\
Teaching remotely during the pandemic & NA & $x^{2}=15.90 ; p=0.72$ \\
\hline
\end{tabular}

$\mathrm{r}=$ Pearson correlation coefficient; $\mathrm{x}^{2}=$ Chi-square; *Statistically significant associations NA - Not applicable. Source: Applied questionnaires. 
Table 3 describes the educational characteristics, environments available, and professors' perceptions during the COVID-19 pandemic. When asked about the devices they had access to for teaching online, all of the professors who taught online reported owning their own computers or tablets, 39 (55\%) reported that they did not share their work device with anyone, $22(31 \%)$ reported that they shared their work device with 1, 2, or 3 people, $8(11 \%)$ reported that they shared their work device with 4 or more people, and $2(3 \%)$ of the professors did not answer the question. On average, each professor shared his or her computer with 1 other person (SD 1 person).

Table 3 - Educational characteristics, environments available, and professors' perceptions during the COVID-19 pandemic.

\begin{tabular}{|c|c|c|c|}
\hline Characteristic & $\begin{array}{l}\text { All } \\
(\mathbf{n}=138)\end{array}$ & $\begin{array}{l}\text { Teaching } \\
\text { Remotely } \\
(\mathbf{n}=71) \\
\end{array}$ & $\begin{array}{l}\text { Not Teaching } \\
\text { Remotely } \\
(\mathrm{n}=67)\end{array}$ \\
\hline \multicolumn{4}{|c|}{$\begin{array}{l}\text { Professor sought information on online teaching methods during } \\
\text { pandemic, } \mathrm{n}(\%)^{\mathrm{a}}\end{array}$} \\
\hline Yes & $120(87)$ & $64(90)$ & $56(84)$ \\
\hline No & $18(13)$ & $7(10)$ & $11(16)$ \\
\hline \multicolumn{4}{|c|}{ Internet access at home, $\mathrm{n}(\%)^{\mathrm{b}}$} \\
\hline Yes & $69(100)$ & $69(100)$ & - \\
\hline \multicolumn{4}{|c|}{ Home environment appropriate for teaching remotely, $\mathrm{n}(\%)^{\mathrm{b}}$} \\
\hline Yes & $48(72)$ & $48(72)$ & - \\
\hline No & $19(28)$ & $19(28)$ & - \\
\hline \multicolumn{4}{|c|}{$\begin{array}{l}\text { Institution provided the professor with training in distance education, } \mathrm{n} \\
(\%)^{\mathrm{b}}\end{array}$} \\
\hline Yes & $62(90)$ & $62(90)$ & - \\
\hline No & $7(10)$ & $7(10)$ & - \\
\hline \multicolumn{4}{|c|}{ Students' type of access to online classes, $\mathrm{n}(\%)^{\mathrm{b}}$} \\
\hline Recorded & $3(4)$ & $3(4)$ & - \\
\hline Real time & $30(44)$ & $30(44)$ & - \\
\hline Both & $35(52)$ & $35(52)$ & - \\
\hline
\end{tabular}

Professor experienced problems with their internet connection while teaching remotely, $\mathrm{n}(\%)^{\mathrm{b}}$

\begin{tabular}{|c|c|c|c|}
\hline Yes & $35(51)$ & $35(51)$ & - \\
\hline No & $34(49)$ & $34(49)$ & - \\
\hline \multicolumn{4}{|l|}{ Professor reported difficulty using electronics to teach online, $\mathrm{n}(\%)^{\mathrm{b}}$} \\
\hline Yes & $23(33)$ & $23(33)$ & - \\
\hline No & $47(67)$ & $47(67)$ & - \\
\hline $\begin{array}{l}\text { Professors' rating }(1-10) \text { of students' learning success in online classes } \\
\text { during the pandemic, mean }(\mathrm{SD})^{\mathrm{b}}\end{array}$ & $6(2)$ & $6(2)$ & - \\
\hline $\begin{array}{l}\text { Professors' rating (1-10) of their ability to concentrate when teaching } \\
\text { online, mean (SD) }\end{array}$ & $6(2)$ & $6(2)$ & - \\
\hline \multicolumn{4}{|l|}{ Professors offered students complementary study materials, $\mathrm{n}(\%)^{\mathrm{c}}$} \\
\hline Yes & $32(49)$ & - & $32(49)$ \\
\hline No & $33(51)$ & - & $33(51)$ \\
\hline $\begin{array}{l}\text { Professors encouraged students to seek out other educational materials } \\
\text { during the pandemic, } \mathrm{n}(\%)^{\mathrm{c}}\end{array}$ & & - & \\
\hline Yes & $58(87)$ & - & $58(87)$ \\
\hline No & $9(13)$ & - & $9(13)$ \\
\hline
\end{tabular}

Professors believe it is feasible to maintain their syllabus schedule when 
teaching online $(\%)^{\mathrm{b} c}$

\begin{tabular}{llll} 
Yes & $48(74)$ & - & $48(74)$ \\
No & $17(26)$ & - & $17(26)$ \\
\hline $\begin{array}{l}\text { Professor participated in administrative activities online during the } \\
\text { pandemic, } \mathrm{n}(\%)^{\mathrm{c}}\end{array}$ & & \\
$\begin{array}{l}\text { Yes } \\
\text { No }\end{array}$ & $65(97)$ & - & $65(97)$ \\
\hline $\begin{array}{l}\text { Professors' rating (1-10) of their performance in administrative activities, } \\
\text { mean (SD) }\end{array}$ & $8(2)$ & - & $2(3)$ \\
\hline
\end{tabular}

${ }^{\mathrm{a} A l l}$ professors ${ }^{\mathrm{b}}$ Professors teaching remotely ${ }^{\mathrm{C}}$ Professors not teaching remotely Source: Applied questionnaires

Table 4 describes associations between professors' teaching conditions or environment and their anxiety scores.

Table 4 - Professors' teaching conditions and environment available for distance education, perceptions of success, and GAD7 scores.

\begin{tabular}{ll}
\hline Characteristic & GAD-7 \\
\hline Reliable internet access & $\mathrm{r}=-0.060 \mathrm{p}=0.477$ \\
Students' learning success in online classes $^{\mathrm{a}}$ & $\mathrm{r}=0.061 \mathrm{p}=0.611$ \\
Electronic materials used in online classes $^{\mathrm{a}}$ & $\mathrm{r}=0.080 \mathrm{p}=0.505$ \\
Physical environment appropriate for online classes $^{\mathrm{a}}$ & $\mathrm{r}=-0.096 \mathrm{p}=0.437$ \\
Number of people with whom professors shared their at-home workspace $^{\mathrm{a}}$ & $\mathrm{r}=0.021 \mathrm{p}=0.859$ \\
Professor received training in distance education $^{\mathrm{a}}$ & $\mathrm{r}=0.090 \mathrm{p}=0.454$ \\
Digital platform used for online classes $^{\mathrm{a}}$ & $\mathrm{r}=0.177 \mathrm{p}=0.141$ \\
Students' type of access to online classes $^{\mathrm{a}}$ & $\mathrm{r}=0.079 \mathrm{p}=0.518$ \\
Problems with internet connection while teaching $^{\mathrm{a}}$ & $\mathrm{r}=0.025 \mathrm{p}=0.834$ \\
Difficulty using electronics $^{\text {a }}$ & $\mathrm{r}=-0.042 \mathrm{p}=0.726$ \\
Concentration to teach online relative to concentration in face-to-face classes $^{\mathrm{a}}$ & $\mathrm{r}=-0.204 \mathrm{p}=0.092$ \\
Additional study materials offered to students during the pandemic $^{\mathrm{b}}$ & $\mathrm{r}=-0.069 \mathrm{p}=0.574$ \\
Guiding students to look for other ways of learning during this period $^{\mathrm{b}}$ & $\mathrm{r}=0.062 \mathrm{p}=0.613$ \\
Feasibility of syllabus schedule when classes are taught remotely $^{\mathrm{h}}$ & $\mathrm{r}=0.048 \mathrm{p}=0.704$ \\
Administrative activities performed online $_{\text {Performance on administrative activities }}$ & $\mathrm{r}=-0.025 \mathrm{p}=0.8415$ \\
\hline
\end{tabular}

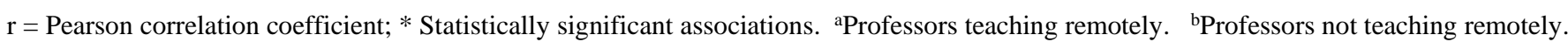
Source: Applied questionnaires.

The electronic devices most commonly used to teach online were desktops and/or laptops (more than $71 \%$ of the professors), while tablets were the least commonly used devices (5\% of the professors). When asked about the platforms used to teach online, Microsoft Teams and Google Meet were reported by $25.7 \%$ and $24.8 \%$ of professors, respectively, and represented the most commonly used programs. YouTube was the least commonly used platform (14.2\%).

Table 5 details the main barriers to teaching online that the professors reported experiencing. It is important to note that the questionnaire allowed them to select more than one option. Difficulty interacting with students was cited by the highest number of professors (34\%), followed by the need to provide childcare while teaching, difficulty concentrating at home, and a lack of an adequate work environment, all of which were reported by between $11 \%$ and $12 \%$ of professors. Poor internet access was only the fifth barrier of difficulty, reported by $9 \%$ of professors. The professors rarely mentioned a lack of training, emotional instability, or fear of the future, all of which were selected by approximately $4 \%$ of professors. 
Table 5 - Numbers and percentages of professors who reported the most commonly reported barriers to successfully teaching online.

\begin{tabular}{lll}
\hline \multirow{2}{*}{ Main Barrier } & \multicolumn{2}{l}{ Professors Teaching Online } \\
\cline { 2 - 3 } & Yes & \% \\
\hline Poor internet access & 15 & $9.1 \%$ \\
Need to provide childcare while teaching & 20 & $12.2 \%$ \\
Difficulty concentrating at home & 19 & $11.6 \%$ \\
Lack of an adequate work environment & 19 & $11.6 \%$ \\
Lack of training & 8 & $4.9 \%$ \\
Difficulty interacting with students online & 56 & $34.1 \%$ \\
Emotional instability & 8 & $4.9 \%$ \\
Fear of the future & 7 & $4.3 \%$ \\
Others & 12 & $7.3 \%$ \\
\hline Total & 164 & $100.0 \%$ \\
\hline
\end{tabular}

Source: Applied questionnaires.

\section{Discussion}

Teaching methods used in undergraduate degree programs in the health sciences have changed in recent decades and have transformed traditional education in which the teacher is the center of the classroom into an environment in which students are the protagonists of their learning. In light of this pedagogical shift, programs from all over the world have gradually increased the number of online courses involved in their curricula (O’Doherty et al., 2018). In Brazil students' and even professors' socioeconomic limitations have hindered the use of online education, including in the health sciences. However, the social distancing restrictions brought about by the COVID-19 pandemic imposed rapid changes on educational programs worldwide, including health-care-related degree programs (Pereira et al., 2021). Some institutions had to stop teaching altogether, while others adopted virtual learning.

It is important to note that Brazilian private institutions offered more distance learning options during the pandemic than did public institutions. This difference may be attributed to private institutions' financial interest in investing in and adapting to distance learning, which included the adoption of virtual platforms, digital media, and training for professors, even prior to the demands of the pandemic. Meanwhile, public institutions required greater adaptation to these platforms and technologies. What's more, the limited financial resources provided to state and federal Brazilian universities, as well as their bureaucratic organizational systems, impeded the rapid changes necessary and culminated in worsened educational outcomes.

According to Farber (2013), in order for an online education program to be successful, it must rely on quality technology infrastructures, provide educators with guidance and support, and include a continuous support system. Because of the urgency in the changes to the modalities used during the pandemic, many teachers did not receive adequate training and were required to adapt in a short period of time. Our research shows that $82 \%$ of professors who taught online had not done so before the pandemic. Of these $82 \%$ of professors, most (64\%) taught at public institutions, and it was these professors who reported the highest levels of anxiety according to their GAD-7 scores.

A challenge to teaching the health sciences online is that many courses are clinical or laboratory-based and thus require physical access to patients or laboratories (Radu et al., 2020). The clinical and laboratory components complement theoretical classes, but because of social distancing restrictions, only theoretical portions or courses were being taught. In our survey, $63 \%$ of professors taught courses that included both theoretical classes and clinical activities. 
In our study, dentistry degree programs had the highest percentage of professors who taught online classes (45\%), but this result likely occurred because dentistry professors had the greatest representation in the sample ( $36 \%$ of respondents).

The educators in our sample averaged 43 years of age. In the case of young adults (professors 35 years of age or younger), age was not found to be a factor correlated with anxiety. An important challenge related to virtual education is that students, in general, are "digital natives," while teachers are "digital immigrants," and many still experience difficulties with computers and the internet (Nuter, 2012; Possolli, Fleury, 2021). Most of the professors in the study reported attempts to learn more about online teaching during the pandemic; only $13 \%$ took no additional courses on this topic.

In this study, the female gender was more strongly correlated with increased anxiety than the male gender. This finding is almost certainly explained by the fact that many women had to take on more household duties, care for their children and organize their studies (since children also stayed home and had their own online classes during the pandemic), and complete their professional activities (such as online classes and administrative meetings) (Adunicamp, 2020). Another factor that was correlated with increased anxiety was household income. If not present before the pandemic, this correlation was likely due to socioeconomic changes and the risks of layoffs from private companies or salary cuts for public employees (whether the professors themselves or their spouses).

In our research, an average of three people lived in each household, and the computer that the professor used to teach remotely was shared with an average of one other person. The physical environment was considered appropriate by $72 \%$ of the professors, but some of them reported difficulties such as their own children requiring attention and difficulty concentrating at home.

Degree programs in the health sciences have long resisted remote learning options; however, the pandemic required programs around the world to quickly adapt to distance education. This change is likely to be irreversible in that many institutions are likely to permanently shift to hybrid online-and-in-person education models.

\section{Conclusion}

Factors such as geopolitical region and university funding source (public versus private institutions) were found to be associated with the likelihood of a university offering courses online. Among professors, the female gender and household income were the factors that were found to be most closely associated with increased anxiety. Difficulties interacting with students during online courses, the need to provide childcare for their own children, and difficulties in concentrating at home were the professors' main barriers to more successful distance education. Further studies should examine the effects of pandemic in way of teaching as well as the impacts of remote teaching on mental health of professors and students.

\section{References}

ADunicamp. (2020) Relatório sobre Condições de Trabalho Remoto Docente na Unicamp Pandemia de COVID-19. Unicamp.

Baker, C. N., Peele, H., Daniels, M., Saybe, M., Whalen, K., \& Overstreet, S. (2020) Trauma-Informed Schools Learning Collaborative. The experience of COVID-19 and its impact on teachers' mental health, Coping, and Teaching. Sch. Psychol. Rev, 50 (4), 1-14, https://doi.org/10.1080/2372966X.2020.1855473

Bergerot, C. D., Laros, J. A., \& Araujo, T. C. C. F. (2014) Avaliação de ansiedade e depressão em pacientes oncológicos: comparação psicométrica. Psico$U S F, 19(2), 187-197$. https://doi.org/10.1590/1413-82712014019002004

Bianchi Zizzias, E. A. (2021) La Educación Superior frente a los desafíos de la pandemia Covid-19 y el uso de las nuevas tecnologías. Observatorio Provincial de Educación Superior, 2(3), 26-30.

Bielschowsky, C. E. (2018) Qualidade na Educação Superior a Distância no Brasil: Onde Estamos, para Onde Vamos? EaD Em Foco, 8 (1), 1-26. https://doi.org/10.18264/eadf.v8i1.709

Farber, R. S. (2013) Distance Education and Teaching Online: My Journey from Mystery to Mastery. Occup Ther Health Care, 27(3), 272-279. https://doi.org/10.3109/07380577.2013.809180 
Research, Society and Development, v. 10, n. 17, e151101724451, 2021

(CC BY 4.0) | ISSN 2525-3409 | DOI: http://dx.doi.org/10.33448/rsd-v10i17.24451

Hinz, A., Klein, A. M., Brähler, E. et al. (2017) Psychometric evaluation of the Generalized Anxiety Disorder Screener GAD-7, based on a large German general population sample. J Affect Disord, 210(1), 338-344. https://doi.org/10.1016/j.jad.2016.12.012.

Kemp, N., \& Grieve, R. (2014) Face-to-face or face-to-screen? Undergraduates' opinions and test performance in classroom vs. online learning. Front Psychol, 5, 1-11. https://doi.org/10.3389/fpsyg.2014.01278

Klapproth, F., Federkeil, L., Heinschke, F., \& Jungmann, T. (2020) Teachers' experiences of stress and their coping strategies during covid-19 induced distance teaching. $J P R, 4$ (4), 444-452. https://doi.org/10.33902/jpr.2020062805

Li, Q., Miao, Y., Zeng, X., Tarimo, C. S., Wu, C., \& Wu, J. (2020) Prevalence and factors for anxiety during the coronavirus disease 2019 (COVID-19) epidemic among the teachers in China. J. Affect. Disord, 277, 153-158. https://doi.org/10.1016/j.jad.2020.08.017

Nutter, L. (2012) Opening address. Online learning: The journey transcending distance. Paper presented at the Northeast E-Learning Consortium at Temple University, Philadelphia, PA.

O'Doherty, D., Dromey, M., Lougheed, J., Hannigan, A., Last, J., \& McGrath, D. (2018) Barriers and solutions to online learning in medical education - an integrative review. BMC Med Educ, 18(130), 1-11. https://doi.org/10.1186/s12909-018-1240-0

Pei, L., \& Wu, H. (2019) Does online learning work better than offline learning in undergraduate medical education? A systematic review and meta-analysis. Med Educ Online, 24(1), 1666538. https://doi.org/10.1080/10872981.2019.1666538.

Pereira, H. S., Araújo, D. D., Xavier Filho, J. R. T., Lima Neto, F. E. M., Brito, M. P., Silva Júnior, E. C., Veras, R. A., Silva, F. M. L., \& Costa, J. M. A. R. (2021) Teacher training: the context of the COVID-19 pandemic and university teaching activities in Brazil. Research, Society and Development, 10 (12), e43101320800. https://doi.org/10.33448/rsd-v10i13.20800

Possolli, G. E., \& Fleury, P. F. F. (2021) Challenges and changes in teaching practice in remote emergency teaching in Higher Education in Health and Humanities. Research Society and Development, 10 (13), e146101320655. http://dx.doi.org/10.33448/rsd-v10i13.20655.

Radu, M. C., Schnakovszky, C., Herghelegiu, E., Ciubotariu, V. A., \& Cristea, I. (2020) The impact of the COVID-19 pandemic on the quality of educational process: A student survey. Int. J. Environ. Res. Public Health, 17 (21), 7770. https://doi.org/10.3390/ijerph17217770

Rose, S. (2020) Medical student education in the time of COVID-19. JAMA, 323(21), 2131-2132. https://doi.org/10.1001/jama.2020.5227

Silva, N. S. S., Cabral, B. R. E., Leão, L. L., Pena, G. G., Pinho, L., Magalhães, T. A., Silveira, M. F., Rossi-Barbosa, L. A. R., Silva, R. R. V., \& Haikal, D. S. (2021) Working conditions, lifestyle and mental health of Brazilian public-school teachers during the covid-19 pandemic. Psychiatriki, 26. 10.22365/jpsych.2021.045.

Spitzer, R. L., Kroenke, K., Williams, J. B. W. et al. (2006) A brief measure for assessing generalized anxiety disorder: the GAD-7. Arch Intern Med, 166(10), 1092-1097. https://doi.org/10.1001/archinte.166.10.1092.

Vieira, J. M, Cardoso, C. A. N., \& Silva, E. G. N. (2021) O ensino remoto em tempos de pandemia: reflexões sobre a prática docente. Research, Society and Development, 10 (13), e470101321329. https://doi.org/10.33448/rsd-v10i13.21329 